\title{
ASSESSMENT OF THE IMPACT OF GOVERNMENT EXPENDITURE OF ENVIRONMENTAL PROTECTION ON THE GDP IN THE CONTEXT OF ENVIRONMENTAL LEGISLATION
}

\author{
Oksana Levytska \\ Lviv Polytechnic National University, Lviv, Ukraine \\ Aliona Romanova \\ Lviv Polytechnic National University, Lviv, Ukraine
}

\begin{abstract}
This article presents a neural network model to forecast government expenditure on environmental protection in the Ukrainian economy. This study focuses on the assessment of the impact of government expenditure on environmental protection on the GDP considering factors that reflect the main elements of economic and environmental policies in developed countries. The result of the study clarifies the extent to which government expenditure on environmental protection should be modified to increase GDP and to strengthen funding for important environmental programs. The relationships between the variables were analyzed by making use of the neural network model. Subject to an increase of public environmental protection spending by $0.01 \%$, GDP will rise on average by $0.36 \%$.
\end{abstract}

Keywords: government expenditure on environmental protection, GDP, neural network model, social and economic variables, forecasting

DOI: http://dx.doi.org/10.15549/jeecar.v7i2.342

\section{INTRODUCTION}

Protecting the natural environment, optimally using natural resources, and enhancing environmental security is important for the Sustainability of a developing country. There is a tendency in developing countries (McCormick, 2001; Eccleston, Charles, 2010; Mirzabaev, Annagylyjova, \& Amirova, 2019) for continual environmental degradation in the form of land cultivation, water consumption, deforestation, atmospheric air pollution, underground water pollution, surface water pollution, soil contamination, and low-quality food.
Environmental costs are an indirect attitude indicator to the environmental issues of the human population and government. Environmental costs include research and development $(R \& D)$ expenses, expenses on education, and so forth. All of this determines the level of environmental culture in society (Lauwerys, 1969; Worster, 1977; Zapf, 2001; Hornborg, 2005; Finke, 2013; Zapf, 2016).

A consistent and coherent environmental policy can provide greater certainty about the value of investments and incentivize 
environmental $R \& D$ further towards a socially optimal level (Andrews, 2008).

Scientists, economists, and ecologists have argued that governments should increase the total expenditure of the general government on innovation and environmental protection (Yurynets, 2016; Vytvytsky \& Kernychna, 2012). A low level of environmental protection expenditure can lead to environmental problems in the future and negative consequences for health.

This paper has a specific objective to assess the impact of government expenditure on environmental protection and different types of social and economic variables on the gross domestic product (GDP). This study focuses on the environmental situation in Ukraine, forecasting government expenditure on environmental protection, taking into account factors that reflect the main elements of economic and environmental policies in developed countries.

In 2016 within Ukraine, the total expenditure of the general government on environmental protection amounted to $0.3 \%$ of GDP. General government expenditure in Ukraine on environmental protection amounted to $0.2 \%$ of GDP in 2017. The trend of expenditures on environmental protection from the State Budget of Ukraine for 2000-2017 has been studied and, after having analyzed it, we have set out several problems: a small number of environmental measures, low level of motivation among enterprises to invest capital in environmental protection and modernization, non-completion of the environmental measures (State budget 2017 and environmental protection, 2017). The main reasons for the annual non-completion of the environmental measures in Ukraine are the following: under-funding of environmental protection programs from the state budget, imbalance in financing for the implementation of environmental programs throughout the year, and postponement of program implementation.

Measuring the efficiency of environmental policy can help the government of Ukraine to benchmark its own environmental protection investment relative to developed countries, identify gaps, and learn from best practices around the world. The result of the study clarifies the extent to which government expenditure on environmental protection should be modified to increase GDP.

\section{LITERATURE REVIEW}

A review of the literature reveals a limited analysis of the concept of the relationship between government policy on environmental protection and the relationship with economic growth, especially using mathematical modeling, indicating a gap in the research. As part of the literature review, methodologies from various academic publications and books were analyzed, and experience with measuring the impact of expenditures on environmental protection on GDP growth in Ukraine and evaluating environmental protection policies were studied.

For the economists Bithas and Kalimeris (2018) and Rosen (2019), several aspects are important, for example, how environmental policy will impact macro variables, such as the level of output in an economy and how environmental policy will impact the long-term growth rate of the economy.

Levinson, Rasmussen, Staehr, and Wrang (2006) asserted that government policies might lead to win-win outcomes, where the environment and the economy are improved at the same time. The traditional approach sees environmental policies as a burden on economic activity, at least in short to medium term, as they raise costs without increasing output and restrict the set of production technologies and outputs. At the same time, Porter's (1995) hypothesis claims that well-designed environmental policies can provide a "free lunch" - encouraging innovation, bringing about gains in profitability and productivity that can outweigh the costs of the policy. For long-term stability and economic growth, increased improvement in the measurement of environmental policy stringency is needed (Koźluk \& Zipperer, 2015).

Different modeling approaches meet these requests and are broadly used. Miller and Blair (1985) identified the main types of environmental models: economic-ecological models, generalized $\mathrm{I} / 0$, and commodity-byindustry models. The neural networks yield 
statistically lower forecast errors for the yearover-year growth rate of real GDP relative to linear and univariate models, the classical GARCH family of models (Saleem \& Ahmad, 2011). Neural networks provide the ability to use a powerful mathematical computing tool for a more efficient and reliable outcome (Zarra et al., 2019).

The use of artificial neural networks for research on ecological politics and the economy has grown significantly over the years. Artificial neural networks have been applied to the simulation of a hybrid renewable microgeneration system with neural network predictive control (Entchev et al., 2018), and for contribution in the environmental and resource economics of Monte Carlo method applications (Baiocchi, 2005).

Some scientists are using neural networks for environmental damage assessment. Moffatt and Hanley (2001) discussed alternative approaches to modeling economy-environment systems from the perspective of sustainable development that use such indicators as the most appropriate population, output, vehicle kilometers, aircraft movements, emissions and GDP. Köhler et al. (2016) provided an overview of modeling activities in the context of EU environment policy that is structured around natural capital, resource efficiency, a low carbon economy, and human health and wellbeing along with the horizontal priority objectives.

Questions are often asked as to how environmental policies designed to protect the environment may harm economic growth. Guo, Xingneng, Sheng and Zhang (2018) showed that policies that stimulate environmental R\&D, technological innovation, green technology innovation and diffusion may provide firms with the correct incentives to prevent damaging the environment, while preserving their competitiveness in the market.

The costs of environmental regulation have been estimated by Boyd and Uri (1991) and Conrad and Schroder (1993) for Germany and the USA. In their analysis of the impact of tracking company environmental spending on environmental and economic performance, Park and Ban (2019) found that environmental performance is positively associated with economic performance.
Scientists are exploring GDP as one of the most important tools to understand the economic health of a country. Pabreja (2018) showed a clear correlation among health, climate, and education-related indicators of various countries as per their development status. Rosen (2019) found that economic intensity and affluence, respectively, and material, resources or pollutants have an impact on continual GDP growth. Ward et al. (2016) demonstrated that growth in GDP ultimately could not be decoupled from growth in material and energy use. The relationship between different factors and GDP has been primarily evaluated in the literature: domestic extraction use (Yu et al., 2013), energy, and material use (Wood et al., 2015).

Pearce and Palmer (2005) found little evidence to show that environmental expenditures negatively impact on economic growth. Krajewski (2016) explained that an increase in public environmental protection expenditure has a positive effect on economic growth. Results revealed that public environmental protection expenditure has a more substantial influence on GDP during a crisis, and its positive effects are most influential in the case of economies affected by the global financial crisis. Based on descriptive statistics and regression analysis of 30 developing countries, Lich and Cam Tu (2019) found that public expenditure increases along with the development level of nations, and economic growth have a positive relationship with investment.

Moreno-Enguix and Bayona (2017) showed significant evidence of an association between public efficiency and state of development, as well as population density, especially in environmental protection. The direction of the association between public sector size and public performance differs per function. Meyer (2019) argued that effective government spending and management have a positive impact on the economy.

Yurynets (2016), Kruglyakova (2016) analyzed the relationship between government policy and economic growth (GDP) and used government revenues and expenditures on research and development, in particular in the area of environmental protection. Government 
spending on environmental protection is a part of total government expenditures, which in a short run usually stimulate the economy (Blanchard \& Leigh, 2013).

Therefore, comprehensively studying the assessment of the impact of government expenditure on environmental protection on the GDP of Ukraine would be reasonable.

The paper is organized as follows. First, the theoretical model, which explains the macroeconomic effects of government expenditure on environmental protection, is presented. Then the results of empirical research, based on the neural network model, are shown. The last paragraph of the paper provides concluding remarks.

\section{METHODOLOGY OF RESEARCH AND EMPIRICAL DATA}

Neural network modeling tools were considered for evaluating the impact of government expenditure on environmental protection on the GDP. Social and economic indicators reflecting budget revenues and expenditures as a percentage of GDP are included in the model. A neural network model based on social and economic indicators of nine developed countries (USA, Austria, Denmark, Great Britain, Norway, Netherlands, Switzerland, Belgium \& Sweden). The study took into account countries that show a high level of social, economic and environmental development and state environmental policy towards the development of environmental protection. In 2017 in the EU-28 and the United States, the total expenditure of the general government on environmental protection has averaged $0.8 \%$ of GDP: Austria - $0.61 \%$, Denmark - $0.6 \%$, Great Britain - $0.66 \%$, Norway $-0.9 \%$, Netherlands $-1.3 \%$, Switzerland $-0.6 \%$, Belgium - $1.23 \%$, Sweden - $0.58 \%$, USA - $0.65 \%$. For the next long-term EU budget 2021-2027, the Commission proposed to increase funding by almost $60 \%$ for LIFE, the EU program for the environment and climate action (Long-term EU budget 2021-2027, 2018). These countries illustrate an example of a quite high level of successfully implemented programs and the optimization of the costs relative to budget revenues (Environmental protection in the association agreement between Ukraine and the EU, 2017).

During the course of the study, the neural network model was developed as an element of economic and mathematical modelling. The model has been constructed for predicting and explaining state environmental policy towards the development of environmental protection.

The model looks into connections between input and output factors, comparing the budget revenues to its costs. The model shows what expenditures should be in Ukraine in line with available budget revenues. The modelling concept primarily provides a framework for building a forecast based on actual performance, preparation of perspective plans considering the forecast and decision analysis within a longterm forecast time.

The most popular neural networks are multiple networks. The multiple networks are put together by hooking together simple neurons. The choice of the structure of the neural network is a problem faced at the beginning of the development of a neural network model. To solve the approximation problem, the following methods can be used: multilayer perceptron, radial basis functions neural networks, generalized regression networks, linear networks.

We developed a modified generalized regression network model, which included the radial basis function (RBF) and multilayer perceptron (MLP). As a result of the work and training of the neural network, it was found that the generalized regression neural network has the radial base layer as the first intermediate layer, and the second middle layer is linear.

The activation value of the neuron is estimated as the difference between the weighted sum of the inputs and the threshold value. The activation function converts the activation signal. The result is the output signal of the $j$ th neuron $\left(u_{j}\right)$ : 


$$
u_{j}=\psi_{j}^{(3)}\left(b_{j}^{(3)}+\sum_{l=1}^{p}\left[w_{l j}^{(3)} \cdot \psi_{l}^{(2)}\left(b_{l}^{(2)}+\sum_{i=1}^{n}\left[w_{i l}^{(2)} \cdot \psi_{i}^{(1)}\left(x_{i}\right)\right]\right)\right]\right), j=\overline{1, m}
$$

where $\psi_{i}^{(1)}$ is the activation function of the $I^{\text {th }}$ neuron of the input layer of a neural network, $i=\overline{1, n} ; \psi_{l}^{(2)}, b_{l}^{(2)}$ is the activation function and the shift parameter for adder $i^{\text {th }}$ neuron of the second layer, $l=\overline{1, p} ; \psi_{j}^{(3)}, b_{j}^{(3)}$ is the activation function and the shift parameter for adder $f^{\text {th }}$ neuron of the output layer, $j=\overline{1, m}$; $w_{i l}^{(2)}$ is the weight of the inter-neural communication between the $I^{\text {th }}$ neuron of the first layer and the $l^{\text {th }}$ neuron of the second layer; $w_{l j}^{(3)}$ is the weight of the inter-neural communication between the $l^{\text {th }}$ neuron of the second layer and the $f^{\text {th }}$ neuron of the output layer of the perceptron; $x_{i}$ is $i^{\text {th }}$ input signal of a neuron.

Input variables were selected: paid taxes and fiscal charges, \% of GDP (C1); business profits tax funds, \% of GDP (C2); personal tax returns, \% of GDP (C3); VAT and excise duty receipts, \% of GDP (C4); summary budget non-tax receipts, \% of GDP (C5); local budget tax receipts, \% of GDP (C6); money supply MS1, \% of GDP.

Statistics variables from 2000 through 2017 for the construction of a model to evaluate state environmental policy and development of environmental protection of Ukraine are presented in Table 1.

Table 1. Statistics variables for the construction of model to evaluation of state environmental policy and development of environmental protection of Ukraine (\% of GDP)

\begin{tabular}{|c|c|c|c|c|c|c|c|c|c|c|c|c|c|c|c|c|c|c|}
\hline Variables & 2000 & 2001 & 2002 & 2003 & 2004 & 2005 & 2006 & 2007 & 2008 & 2009 & 2010 & 2011 & 2012 & 2013 & 2014 & 2015 & 2016 & 2017 \\
\hline C1 & 29,1 & 27,9 & 30,6 & 29,8 & 26,3 & 30,3 & 31,6 & 30,5 & 31,4 & 31,7 & 29,0 & 30,6 & 31,6 & 29,5 & 23,5 & 29,2 & 27,1 & 27,4 \\
\hline $\mathrm{C} 2$ & 4,51 & 4,13 & 4,21 & 4,92 & 4,70 & 5,31 & 4,80 & 4,81 & 5,1 & 3,60 & 3,71 & 4,22 & 4,0 & 3,72 & 2,60 & 4,52 & 4,13 & 4,25 \\
\hline C3 & 3,73 & 4,35 & 4,83 & 5,10 & 3,81 & 3,92 & 4,23 & 4,82 & 4,80 & 4,92 & 4,72 & 4,63 & 4,85 & 4,80 & 4,80 & 3,74 & 4,13 & 4,12 \\
\hline $\mathrm{C} 4$ & 6,91 & 6,42 & 7,77 & 6,70 & 6,79 & 9,48 & 10,8 & 9,72 & 11,1 & 11,6 & 11,7 & 13,3 & 13,1 & 12,1 & 14,0 & 13,7 & 12,6 & 12,9 \\
\hline C5 & 7,39 & 6,91 & 7,22 & 6,19 & 5,91 & 5,92 & 5,90 & 5,33 & 4,83 & 7,01 & 5,71 & 4,63 & 5,72 & 5,62 & 5,10 & 7,40 & 6,92 & 6,97 \\
\hline C6 & 6,89 & 7,22 & 7,33 & 5,71 & 5,21 & 5,22 & 5,61 & 6,12 & 6,20 & 6,41 & 6,23 & 5,61 & 6,10 & 6,11 & 5,60 & 6,90 & 7,45 & 7,34 \\
\hline $\mathrm{C} 7$ & 12,3 & 14,6 & 17,8 & 19,3 & 19,5 & 22,3 & 22,7 & 25,2 & 23,8 & 25,6 & 26,5 & 24,1 & 26,1 & 29,9 & 34,8 & 35,1 & 36,3 & 36,4 \\
\hline MS1 & 13,9 & 15,9 & 16,5 & 19,1 & 21,9 & 21,1 & 23,0 & 26,2 & 24,5 & 16,6 & 13,9 & 15,5 & 15,4 & 14,3 & 13,1 & 14,2 & 14,5 & 14,7 \\
\hline N1 & 0,3 & 0,3 & 0,3 & 0,3 & 0,3 & 0,4 & 0,4 & 0,3 & 0,3 & 0,3 & 0,3 & 0,3 & 0,3 & 0,3 & 0,2 & 0,3 & 0,3 & 0,2 \\
\hline N2 & 0,005 & 0,028 & 0,020 & 0,034 & 0,018 & 0,006 & 0,021 & 0,020 & 0,036 & 0,014 & 0,008 & 0,012 & 0,015 & 0,002 & 0,019 & 0,005 & 0,028 & 0,029 \\
\hline N3 & 0,36 & 0,38 & 0,32 & 0,40 & 0,42 & 0,39 & 0,37 & 0,39 & 0,41 & 0,38 & 0,35 & 0,29 & 0,32 & 0,29 & 0,29 & 0,36 & 0,3 & 0,32 \\
\hline N4 & 28,3 & 27,2 & 26,7 & 28,4 & 29,3 & 32,1 & 32,2 & 31,4 & 32,6 & 33,6 & 34,9 & 32,0 & 34,9 & 33,6 & 33,4 & 30,3 & 31,2 & 31,3 \\
\hline N5 & 3,89 & 3,81 & 3,82 & 3,72 & 3,64 & 3,52 & 3,71 & 3,41 & 3,19 & 3,71 & 4,10 & 3,82 & 3,91 & 4,10 & 3,70 & 3,89 & 3,82 & 3,80 \\
\hline N6 & 2,31 & 2,33 & 2,12 & 2,20 & 2,11 & 2,21 & 2,23 & 2,10 & 2,31 & 2,61 & 2,70 & 2,12 & 2,10 & 2,10 & 1,80 & 2,32 & 2,33 & 2,32 \\
\hline
\end{tabular}

Source: formed according to (State Statistics Service of Ukraine, 2018).

Output variables also were selected: government expenditure on environmental protection, \% of GDP (N1); state budget expenses for innovation activity, \% of GDP (N2); 
state budget expenses for R\&D, \% of GDP (N3); summary budget expenditures, \% of GDP (N4); local budget expenses for the countrywide functions, \% of GDP (N5); state budget expenses for education, \% of GDP (N6).

During the automatic formation of the neural network, the STATISTICA Automated Neural Networks was applied. An option to create a network in the initial dialog box was chosen for time series regression and forecasting. After that, a set of dependent and independent variables were selected.

The statistical data over the period 1979-2017 was employed for modelling and forecasting. Data collected by OECD, IMF and the State Statistics Committee of Ukraine for statistical purposes were used for data analysis.

A predicted level of financing of environmental protection from the state budget is the final result of neural network modeling.

In the simulation, an expert evaluation has been used within $[0 ; 1]$. The high level of state environmental policy towards the development of environmental protection is represented by 1 . In contrast, the low level of state environmental policy towards the development of environmental protection is represented by 0 .

\section{RESEARCH RESULTS}

A maximum and a minimum number of neurons, the networks for training, the interfaces for selection and evaluation were determined before the training of the neural network. Then the training and selection of the necessary networks were started. The neural model correctly and logically interprets the data content.

During the simulation, the multilayer perceptron MLP 12-14-1 was received. This neural network had the smallest learning error and the highest performance.

During 2000-2017, a decreasing trend of the specific weight of the government expenditure on environmental protection in GDP was noticed in Ukraine (Table 1). The study took into account real GDP adjusted to remove price changes.

There is a direct correlation between the amount of government expenditure on environmental protection and the evaluation of a neural network of how well an existing public environmental policy was functioning.

As shown in figure 1 , the increase in government expenditure on environmental protection leads to GDP growth. Subject to the increase of public environmental protection spending by $0.01 \%$ GDP will rise on average by $0.36 \%$. The neural model shows that environmental expenditures in Ukraine should be higher, taking into account available budget revenues. The calculations would represent a realistic scenario.

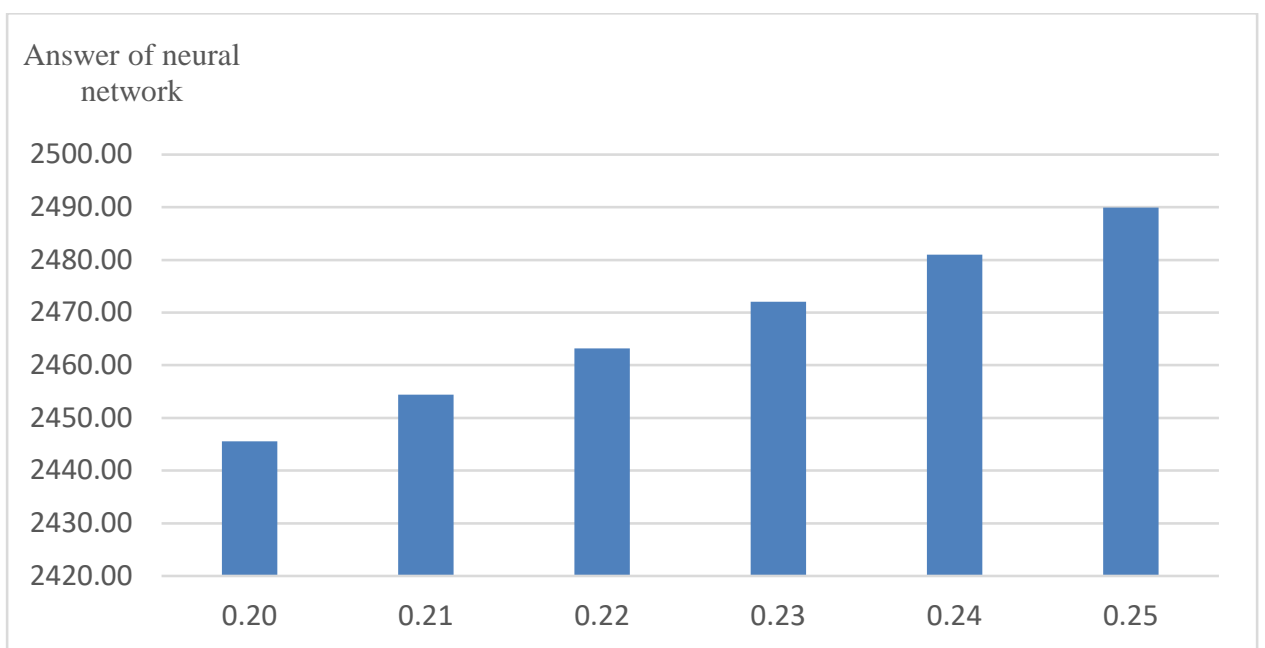

Figure 1. The influence of government expenditure on environmental protection over GDP (\% of GDP).

Source: Developed by authors. 
One dimension of the strengthening of developed countries was the promotion of environmental protection activities. The expenses provide environmental protection projects for environmental activities. Besides the increase of state budget expenses for environmental protection, also required is the provision of alternative sources of funding: formation of environmental funds in Ukraine with the use of venture financing; ecological tax base expansion; increase fines for violations of environmental laws; improve management of official development assistance to Ukraine in the area of environmental protection; provide loans for the development of businesses introducing eco-innovations.

We do not agree that the cost of stabilization and rehabilitation of the environment (Explanatory note to the Draft Law of Ukraine, 2019) should be reduced. We support the ideas of scientists (Yurynets \& Kruglyakova, 2016; Yurynets, Bayda \& Petruch, 2015; Marushevsky \& Rudenko, 2017) who believe that the sustainable development of Ukraine, high quality of life and health of the population can be achieved only through conservation and improvement of the environment. To this end, it is necessary to formulate and consistently implement uniform state policy in the field of ecology to preserve environmental protection and rationally use natural resources. The restoration and preservation of the environment must be one of the state's and society's priorities. The implementation of environmental projects allows us to achieve the desired result in addressing environmental problems. The state will gradually receive results from environmental protection projects.

\section{CONCLUSIONS}

A review of the literature and empirical results from previous research indicate the importance of identifying the impact of factors on GDP growth. The primary objective of this study was to define, using neural network modelling, the impact of government expenditure on environmental protection and different types of social and economic variables related to government activities on GDP growth.
The results confirmed that the independent variable (government expenditure on environmental protection) causes changes in GDP. Subject to the increase of public environmental protection spending by $0.01 \%$ GDP will rise on average by $0.36 \%$. The implications of the study are that the government of Ukraine can improve the environmental situation in the country and play a considerable role in GDP growth and development of environmental activities, as is shown in this study by using neural network modelling on input and output variables reflecting the social and economic policies of the country. The advantage of the study is that the time frame is relatively current - from 1979 to 2017. A recommendation from the study is that funding for important environmental programs should be strengthened.

Future study should include other factors and some comparative research. With respect to comparative research we plan to perform an analysis of post-Soviet countries, and to compare these countries to European states and to use the model to forecast expenditures on environmental protection in developed countries and compare the growth in these expenditures with the forecast for Ukraine. Because the proposed model does not take into account all the factors that may affect the formation of economic and environmental processes in Ukraine, such as the exchange rate, political factors, risks. A future study should analyze the impact these factors have on gross national product.

In conclusion, the study's results confirm that full financing of environmental programs will allow the timely implementation of ecological programs made for Ukraine's sustainable development to eliminate one of the reasons for non-compliance with environmental measures and low efficiency of their use in Ukraine.

This question is relevant to various environmental issues: waste disposal, rational use of natural resources; implementation of environmental protection measures; and state support for the most effective ways to decrease greenhouse gas emissions. Any of these positive effects, however, can be increased utilizing an increase in government expenditure on environmental protection. 


\section{REFERENCES}

Andrews, M. (2008). The good governance agenda: Beyond indicators without theory, Oxford Development Studies, 36, 4, 379407.

Baiocchi, G. (2005). Monte Carlo methods in environmental economics. Applications of simulation methods in environmental and resource economics. The economics of nonmarket goods and resources, 6, Springer, Dordrecht.

Bithas, K., \& Kalimeris, P. (2013). Re-estimating the decoupling effect: is there an actual transition towards a less energy-intensive economy? Energy, 51, 78-84.

Blanchard, O., \& Leigh, D. (2013). Growth forecast errors and fiscal multipliers, IMF Working Paper, 13, 1. Retrieved September 10, 2019 from

https://doi:https://www.imf.org/external/p ubs/ft/wp/2013/wp1301.pdf

Boyd, R., \& Uri, N.D. (1991). The cost of improving the quality of the environment, Journal of Policy Modelling, 13, 1, 115-140.

Eccleston, C. H. (2010). Global environmental policy: concepts, principles, and practice.

Entchev, E., Yang, L., Ghorab, M., Rosato, A., \& Sibilio, S. (2018). Energy, economic and environmental performance simulation of a hybrid renewable microgeneration system with neural network predictive control, Alexandria Engineering Journal, 57, 1, 455473.

Environmental protection in the association agreement between Ukraine and the EU. EUUkraine civil society platform report (2017)

Retrieved March 2, 2019 from https://www.civic-synergy.org.ua/wpcontent/uploads/2018/04/Dovkillia-Fin6.pdf [in Ukrainian]

Finke, P. (2013). A brief outline of evolutionary cultural ecology, Traditions of systems theory: major figures and contemporary developments, ed. Darrell P. Arnold, New York: Routledge.

Guo, Y., Xingneng, X., Sheng, Z., \& Zhang, D. (2018). Environmental regulation, government R\&D funding and green technology innovation: evidence from China Provincial Data, Sustainability, 10, 4, 940.

Hornborg, A. (2005). Cultural ecology. Berkshire Publishing Group.

Köhler, J., Glöser, S., Pfaff, M., Corbin, M., Hogg, D., Sørensen, M.M, \& Maratou, A. (2016). Scoping study on modelling of EU environment policy. Luxembourg: Publications Office of the European Union.

Koźluk, T., \& Zipperer, V. (2015). Environmental policies and productivity growth - a critical review of empirical findings. OECD Journal: Economic Studies, № 1. Retrieved May 07, 2019 from http://www.oecd.org/economy/growth/Envi ronmental-policies-and-productivitygrowth-a-critical-review-of-empiricalfindings-OECD-Journal-Economic-Studies2014.pdf

Krajewski, P. (2016). The impact of public environmental protection expenditure on economic growth, Problemy ekorozwoju problems of sustainable development, 11, 2, 99-104.

Lauwerys, J. A. (1969). Man's impact on nature: Aldus Books, London.

Levinson, A., Rasmussen, C., Staehr, K., \& Wrang, K. (2006). "What are the linkages between environmental policies, economic growth and employment?". Green Roads to Growth. Copenhagen: Environmental Assessment Institute, 28-88.

Lich, H., \& Cam Tu, D. (2019). The Optimal Public Expenditure in Developing Countries, $V N U$ Journal of Science: Economics and Business, 2, 35, 41-51.

Long-term EU budget 2021-2027 (2018). Retrieved May 05, 2019 from https://ec.europa.eu/commission/news/long -term-eu-budget-2021-2027-2018-jun01_en

Marushevsky, G. B., \& Rudenko, L. G. (2017). The future of Ukraine is in the implementation of the sustainable development strategy until 2030, Ukrainian Geographical Journal, 2, 32-39.

Meyer, D. F. (2019). A quantitative assessment of the impact of government activities on the economy of Poland, Journal of Eastern 
European and Central Asian Research, 6, 2, 220-233.

McCormick, J. (2001). Environmental policy in the European Union. The European Series. Palgrave.

Miller, R. E., \& Blair, P. D. (1985). Input-output analysis: foundations and extensions. Prentice-Hall, Englewood Cliffs, NJ.

Mirzabaev, A., Annagylyjova, J., \& Amirova, I. (2019). Environmental degradation. The Aral Sea Basin, 67-85

Moffatt, I., \& Hanley, N. (2001). Modelling sustainable development: systems dynamic and input-ouput approaches.

Environmental Modelling \& Software, 16, 545-557

Moreno-Enguix, M. D. R., \& Lorente Bayona, L. V. (2017). Factors affecting public expenditure efficiency in developed countries, Politics \& Policy, 45, 1, 105-143

Pabreja, K. (2018). Anticipation of gross domestic product using world development indicators. ICT Based Innovations, 141-151

Park, K.-W., \& Ban H.-J. (2019). The effect of tracking of environmental costs on environmental performance and economic performance. Retrieved May 08, 2019 from https://doi:10.23839/kabe.2019.34.5.541

Pearce, D., \& Palmer, C. (2005). Public and private spending for environmental protection: a cross-country policy analysis Fiscal Studies, 22, 4, 403-56

Porter, M. E., \& van der Linde, C. (1995). Towards a new conception of the environmental competitiveness relationship, Journal of Economic Perspectives, 9, 97-118.

Rosen, R. A. (2019). Temperature impact on GDP growth is overestimated. Proceedings of the National Academy of sciences, 116, 33. Retrieved May 08, 2019 from https://doi: 10.1073/pnas.1908081116

Saleem, S., \& Ahmad, Z. (2011). Performance evaluation of different models for volatility forecasting of asset prices. 8th International Conference on Recent Advances in Statistics, At Lahore, Pakistan. Retrieved May 05, 2019 from https://doi: 10.13140/2.1.1852.1604

State budget 2017 and environmental protection (2017). Retrieved May 05, 2019 from

https://ecoclubua.com/2016/10/derzhavnyjbyudzhet-2017-i-ohorona-dovkillya/

State Statistics Service of Ukraine (2018). Official web site, Statistical data and various reports. Retrieved May 06, 2019 from: http://www.ukrstat.gov.ua/.

Vytvytsky, Ya. S., \& Kernychna, A. E. (2017). Mekhanizm derzhavnoho upravlinnya v ekolohichniy sferi na rehional'nomu rivni ta napryamy yoho vdoskonalennya [Mechanism of public administration in the ecological sphere at the regional level and directions of its improvement], Actual problems of public administration, 2,42 , 178-186 [in Ukrainian].

Ward, J. D., Sutton, P. C., Werner, A. D., Costanza, R., Mohr, S. H., \& Simmons, C. T. (2016). Is decoupling GDP growth from environmental impact possible? PLoS One, 11, 10. Retrieved May 08, 2019 from https://doi:10.1371/journal.pone.0164733.

Wood, R., Stadler, K., Bulavskaya, T., Lutter, S., Giljum, S., de Koning, A., Kuenen, J., Schütz, H., Acosta-Fernández, J., Usubiaga, A., Simas, M., Ivanova, O., Weinzettel, J., Schmidt, J.H., Merciai, S., \& Tukker, A. (2015). Global sustainability accounting-developing exiobase for multi-regional footprint analysis, Sustainability, 7, 138-163.

Worster, D. (1977). Nature's economy. Cambridge University Press

Yu, Y., Chen, D., Zhu, B., \& Hu, S. (2013). Ecoefficiency trends in China, 1978-2010: decoupling environmental pressure from economic growth, Ecological Indicators, 24, 177-184.

Yurynets, Z. (2016). Forecasting model and assessment of the innovative and scientifictechnical policy of Ukraine in the sphere of innovative economy formation Investment, Management and Financial Innovations, 13, 2, 16-23.

Yurynets, Z. V, \& Kruglyakova, V. V. (2016). Neyromerezheve modelyuvannya yak instrument prohnozuvannya innovatsiynoho rozvytku ekonomiky Ukrayiny [Neural network modeling as a tool for predicting the innovative development of the Ukrainian economy], 
Current Problems of the Economy, 6, 180, 425-432. [in Ukrainian].

Yurynets, Z., Bayda, B., \& Petruch, O. (2015). Country's economic competitiveness increasing within innovation component, Economic Annals - XXI, 9-10, 32-35.

Zarra, T., Galang, M. G., Ballesteros, F. Jr., Belgiorno, V., \& Naddeo, V. (2019). Environmental odour management by artificial neural network - A review, Environment international, 133, Retrieved May 08, 2019 from https://doi:10.1016/j.envint.2019.105189

Zapf, H. (2001). Literature as cultural ecology: notes towards a functional theory of imaginative texts, with examples from American literature, Yearbook of Research in English and American Literature, 17, 85-100.

Zapf, H. (2016). Literature as cultural ecology: sustainable. Texts: Bloomsbury Academic, London.

\section{ABOUT THE AUTHORS}

Oksana Levytska, email: aa54321@i.ua

Dr. Oksana Levytska is an Assistant Professor of the Theory and Philosophy of Law, Institute of Law and Psychology of the Lviv Polytechnic National University, Candidate of the science of Law. Investigates the problems of the philosophy of law, canon law, financial and legal security, sociology of the law of the peculiarities of anthropology of truth in the law. She takes an active part in the elaboration of the department research concerning "Metanthropological concept of state formation and law creation." She is the author of textbooks in the philosophy of law and over 100 scientific papers and reports.

Dr. Aliona Romanova is a Professor at the Department of Theory and Philosophy of Law, Institute of Jurisprudence, and Psychology of Lviv Polytechnic National University. Professor Romanova investigates the issues of the anthropology of law, financial and legal security, peculiarities of human life in the natural and legal environment, particularly for the period of social and legal anomy. She takes an active part in the elaboration of the department research concerning "Meanthropological concept of state formation and law creation." She is the author of textbooks in the philosophy of law and over 150 scientific papers and reports. 